\title{
The Role of School Management in Enhancement of Foreign Language Education
}

\author{
Rais F. Shaikhelislamov ${ }^{1} \&$ Alsu N. Makhmutova ${ }^{1}$ \\ ${ }^{1}$ Kazan (Volga region) Federal University, Kazan, Russia \\ Correspondence: Rais F. Shaikhelislamov, Room No. 217, Orenburgskii trakt 4a, Kazan, 420059, Russian \\ Federation. E-mail: shraisf@rambler.ru
}

Received: December 29, 2014

doi:10.5539/res.v7n4p198

\author{
Accepted: January 22, 2015 Online Published: February 11, 2015 \\ URL: http://dx.doi.org/10.5539/res.v7n4p198
}

\begin{abstract}
Improvement of foreign language teaching in schools is a major political and social challenge in today's globalized world. Transition to competence-based paradigm requires proficiency in new methodology, curriculum design and assessment techniques. The present article examines the specifics of the implementation of new Federal State Educational Standards (FSES) in the context of foreign language teaching in Russia. The purpose of the article is to describe the authors' conception on achieving the Standards requirements in foreign language schooling. In the beginning, this paper highlights the reasons for prioritizing foreign language proficiency at school level and evaluates the situation with foreign language teaching in the Russian Federation. Further, the paper looks at the traditional roles of teachers in a teacher-centred classroom that is detrimental to the development of learners' personality. The paper then goes on to present key innovative multi-facet roles of the foreign language teacher. The conceptual approach focuses on the prerequisites for the development of a new socio-educational environment and gives educators practical advice concerning the ways of successful transmuting the FSES requirements into foreign language teaching.
\end{abstract}

Keywords: competence-based approach, foreign language education, teacher roles, education management in FLT

\section{Introduction}

\subsection{Significance of the Problem}

Development of information technology have triggered significant changes in global economy and social life. Education system must respond to these changes to be confident that younger generation is well prepared to work and live in the new conditions. Current reforming in the education system of Russia is predominantly determined by worldwide tendencies in pedagogic sciences, the foundation of which makes up the transition from knowledge-focused teaching practices to a more practical methodology targeted on the development of competences as an ultimate goal of any training, including foreign language teaching.

Today management of educational institutions as well as foreign language teachers in Russia must design their curriculum in agreement with the academic achievements featured in new Federal State Educational Standards (FSES). It is the competence-based approach that underlies the core of the FSES, which determine the foreign language syllabus as a set of competencies. However, the implementation of FSES faces numerous difficulties, one of which is due to the fact that all-level educators are not fully aware of new conceptions featured by the Standards. Consequently, various stakeholders have disparate views both on theory and on practice of competence-based approach in foreign language teaching. The basic assumption is that successful implementation of the new approach and the Standards depends on teachers and administrators expertise in translating the Standards requirements into school and classroom practices, assessment techniques and procedures.

Before addressing the main issues of FSES implementing, the next sections dwell on fundamental principles regulating current education reforms and language policies all over the globe.

Political, social and cultural context of foreign language education in the modern world

Traditions of economically leading countries proves that community proficiency in other languages is a national heritage gained throughout the long history. At the beginning of the XXI century most governments all over the 
world acknowledged that successful teaching of additional languages at school level is a key contributor to the state's success in the international arena.

Accordingly, in a 2006 report entitled, Education for Global Leadership: The Importance of International Studies and Foreign Languages for U.S. Economic and National Security, the Committee for Economic Development declared, "To confront the twenty-first century challenges to our economy and national security, our education system must be strengthened to increase the foreign language skills and cultural awareness of our students. America's continued global leadership will depend on our students' abilities to interact with the world community both inside and outside our borders." (Partnership for 21st Century Skills, 2011)

As for the united Europe, foreign language skills of its citizens promote social and economic cohesion of the EU. Multilingualism and cultural diversity of the EU raise the issue of joint prosperity and mutually advantageous cooperation between the Member States, which significantly differ in languages, cultures, and historical traditions. Thus, a 2005-2007 research, commissioned by the Directorate General for Education and Culture of the European Commission, into the effects of language barriers in enterprises on the European economy interrelated language skills and export success of small and medium enterprises. The final report stated, " $11 \%$ of exporting European small and medium enterprises (945,000 companies) may be losing business because of identified communication barriers." (CILT, 2006) As a result, the Commission suggested four elements of language management to facilitate successful export performance, among which are having a language strategy, using translators/interpreters and recruiting staff with the target language skills (CILT, 2006).

It is unsurprising that in 2002, the Barcelona European Council recommended that at least two foreign languages should be taught to all pupils from a very early age (Barcelona European Council, 2002, p. 19). Thus, according he Eurostat data on foreign language learning for the 2007/08 school year, the most widely studied foreign languages in schools are English (38\%), French (12\%), German (11\%), Spanish (7\%) and Russian (5\%) (European Commission, 2012).

In September 2008, Commission of the European Communities (2008) adopted a Communication titled "Multilingualism: an asset for Europe and a shared commitment", which was followed in November 2008 by a Council Resolution on a European strategy for multilingualism. The Communication addressed languages in the context of social cohesion and prosperity and focused on actions to encourage and assist citizens in acquiring foreign language skills.

EU language policy developers believe that in the current context of increased intercultural collaboration mastering the national language(s) is fundamental to fostering dialogue and mutual respect between European citizens. Language skills greatly contribute to mobility, employability and a competitive edge for European businesses (Eurostat, 2014).

The 2005 National Statement for Languages Education in Australian Schools asserted a priority for Asian languages associated with key trading partners (MCEETYA, 2005). Moreover, as early as mid-2009, the federal government funded, specifically \$62.4 million over 2008-09 to 2010-11, for the National Asian Languages and Studies in Schools Program (NALSSP). Intending to considerably increase the number of Australian students proficient in the languages and understanding the cultures of China, Indonesia, Japan and Korea, NALSSP targeted increases in the number of Asian language classes and Asian language teachers in schools and planned to develop a specialist curriculum for 'advanced' language students" (Lo Bianco \& Slaughter, 2009, p. 24).

Thus, experience of leading countries shows that despite the specificity in the vision of the nation-state's success and prosperity, there is a unanimous awareness among their authorities that foreign language literacy is an asset of strategic importance.

\subsection{Challenges of Foreign Language Teaching in Russia}

Integration of Russia into the global economy significantly broadened the social context of foreign language acquisition. Today Russian education is being reformed to give a much more prominent role to foreign languages and intercultural communication skills in schooling. "Learning a foreign language is a priority of modern schooling. A foreign language, as an academic subject, integrates language and essentials of literature (introducing samples of foreign literature). It can be both a goal and a means of studying other subject areas (humanities, natural sciences, technology) (Prosveshenie, 2011, pp. 15-16). Thus, opening the II International Conference "Language and Culture" (Moscow, 2003), Russian President Vladimir Putin said, "The study of languages and cultural traditions promotes mutual understanding between people, helps solve complex political and socio-economic issues of the day".

As early as in 2002, the Russian government adopted a "Conception on Modernization of Russian Education for 
the Period up to 2010" which formulated a new language policy in the Russian Federation. The Concept identified foreign language literacy and intercultural awareness as an urgent need for Russian society and ascribed better social adaptation to the language competence.

The Conception (2002) obliged schools to upgrade second language skills to the range of functional literacy and initiate compulsory examination in foreign languages. It is worthy of note that overall social context created favourable conditions for differentiating foreign language learning and a flexible system of choice (Voitovich, 2012, p. 19).

However, in reality, an average Russian secondary school graduate still experiences colossal difficulties in using a foreign language or any other national languages of the Russian Federation at the threshold level.

This is unacceptable in the era of globalized economy and increasing international economic relations which entail learning and working in other language environment. Definitely, it is easy to blame schoolteachers for this lack of language proficiency. However, this in fact is not their fault. Firstly, education administrators have practically neglected the second language education. This negligence could easily be detected in the following:

- Secondary schools have only 2 hours per week for learning the second language;

- Languages are taught in the absence of the target language milieu;

- Communication activity of schoolchildren is scarce; preference is mainly given to writing or reading and occasionally to pair work;

- The learning process is not regular, holidays and other long breaks negatively affect in second language acquisition;

- Heads of most educational institutions do not speak any foreign language themselves, neither they are familiar with modern methods of language education management;

- Material and technical supplies as well as information and methodological support of schools do not meet challenges of current second language teaching;

- Most schools failed to develop organizational and educational mechanisms to monitor students' foreign language achievements;

- Teacher education still focuses on the active role of teachers to the detriment of communication;

\section{Conceptual Framework}

\subsection{New Federal State Educational Standards for the Foreign Language in Russia}

The 2011-2012 Federal state educational standards (FSES) and the Education Act (2012) defined totally new requirements for school management of the language education. The new standards address foreign languages along with the Russian language and literature as a compulsory subject constituting the field of philology and contributing to the communicative culture of schoolchildren. In this case, the main objective of the school second language education is identified as "the development of foreign language competence, that is, competency in a foreign language cross-cultural interpersonal communication with native speakers" (Prosveshenie, 2011, pp. 15-16).

Thus, the new FSES institutionalized foreign language learning at earlier grades of schooling, that is, at the second grade. Consequently, primary schools today are already teaching foreign language by the new standards. According to the FSES, second grade learners are supposed to make small talks (e.g. talking to a friend, congratulating, thanking and greeting); asking and answering to a series simple queries; talking about themselves and family or a friend; providing description of nature, school, etc. using model sentences and phrases (Savinov, 2010, p. 35).

The fifth grade students are able to communicate about advanced topics in all forms of interpersonal conversations and monologues articulating their ideas about listening/reading or project work. To reach this proficiency range they must learn how to discuss and converse about a familiar topic; make inquiries; ask for clarification; agree or disagree with a partner; express their thoughts about a topic; make reports communicating main ideas about a topic / issue; give the gist of newly received information, talk about themselves and their environment, plans for the future, justify their intentions and actions; discuss facts and events giving examples, outlining their arguments and drawing inferences; describe lifestyle and culture of Russia and the target language culture. (Savinov, 2011, p. 219).

The ninth grade students are able to converse in standard informal situations following the norms of the acquired language; take and give interviews; communicate about themselves, their family, friends, school, interests and 
future plans; provide information about their town / village, daily life of Russia and the target language countries using visual and / or verbal cues such as keywords, an outline, questions; describe events using visual and / or verbal cues; provide descriptions of real life people and fictional characters; render texts using the target text or other cues such as keywords, an outline or questions (Savinov, 2011, pp. 60-61).

In line with Educational Standard of Secondary (Complete) General Education for the Foreign Language (2012) the eleventh grade students are able to hold both formal and informal conversations on a wider range of advanced topics using evaluative judgments; present themselves and their plans for the future; relate reading / listening to discuss problems abiding the rules of etiquette; describe their environment, debate familiar topics and issues; provide socio-cultural description of Russia and the target language country

These educational objectives require a fundamentally new approach to foreign language education, since it is not possible to achieve them solely with foreign language teachers who meet students 3 or 4 times per week. Therefore, it is imperative to impart foreign languages skills and knowledge of current language teaching to school and education administrators.

Innovation and enhancement of foreign language education in schooling are related to the educational reforms in Russia, which in turn are based on The National Educational Initiative "Our New School". The Initiative (2010) comprises six main lines of education development. These lines are:

1) Implementation of new educational standards;

2) Elaboration of advanced search and support networks for gifted children with further monitoring of these children during their formative years;

3) Launching regular projects aimed at upgrading and updating teaching staff and an incentive scheme for the most efficient specialists in the field;

4) New guidelines for work, design, construction and logistical support of schools. The basic criterion is the high level and sense of comfort at schools.

5) Paying individual attention to each student, which allows to minimize health risks in the learning process;

6) The growth of school autonomy.

As has been mentioned above, the implementation of the FSES has become the key pillar of the educational reforms. The mandatory implementation of the FSES for primary schools in all educational institutions of Russia started in the 2011-2012 academic year. The FSES for general basic education begins to function everyplace in Russia in the 2015-2016 academic year and for general secondary (complete) education it starts in the 2020-2021 academic year.

\subsection{Classroom Roles of Foreign Language Teachers: Traditional and Innovative}

\subsubsection{Teacher as a Target of Educational Reforms}

The ultimate target of all language education reforms is the efficiency of teachers, involving their skills, expertise and performance. How far are ready foreign language teachers and schools to educate by the new standards?

Experience shows that teachers still encounter a range of difficulties in fulfilling the standards. Numerous questions from schoolteachers attending our retraining and further training courses at the Volga Region Center for Further Training and Professional Retraining of Kazan Federal University prove this fact. Similar problems exist in other regions of Russia. Accordingly, the authors of the teaching-aid package "Angliiskii yasyk 2-11" (Peregudova et al.) surveyed 223 foreign language teachers from 16 regions of the Russian Federation to identify causes which impede progress in achieving the FSES educational results. They ultimately identified three groups of problems faced by foreign languages teachers when switching to the new standards.

The first group focuses on confusion between the first and second generation standards. Teachers find it difficult demarcate between the knowledge-focused and educational paradigms (26\%), foreign language lessons and lessons of foreign-language education (22\%), subject-related outcomes and academic outcomes (19\%), process of knowledge, abilities and skills development and communicative technologies of foreign language teaching (23\%).

Problems of the second group address classroom development of academic outcomes. The majority of the teachers, as it turned out, have difficulties with setting correct goals to achieve personal development results $(27 \%)$ and meta-subject $(21 \%)$ results.

The third and the most numerous group include problems related to achieving academic outcomes. The most 
difficult problem here is the development of regulatory universal academic actions (26\%) and special academic skills $(20 \%)$. Similarly, schoolteachers face major challenges in founding information and education environment (32\%), personalizing of educational process (28\%) and development of ICT competencies (23\%) (Kouzovlev, 2014).

All these problems, which emerged in response to the new standards, expose completely different challenges and a new model of school management aimed at changing teaching ideology and creating a novel internal educational paradigm.

\subsubsection{The Drawbacks of a Teacher-Centred Approach}

Undoubtedly, the new standards require a different way of organizing children's activities and developing their language skills. Unfortunately, there still dominates teacher-focused practice that gives the leading role to the instructor; that is, when the student is driven by the teacher to learn the subject. Eventually the student turns into a passive object of teaching. This is the main characteristic of the old scholastic education that does not develop leadership qualities nor does it make the student an active subject of learning.

Today, this model has been much criticized in both Russian and world pedagogy. The primary reason for the criticism is a reproductive nature of the education and inequality between its members; the student is only a passive recipient of knowledge. The ultimate goal of this approach is to transmit the student full and substantive knowledge of the issues discussed, as well as assimilate all the information shared by the teacher in the right amount. This approach forces the student to articulate their answers without distorting or modifying the original meaning. As a result, this traditional model produces students with deep knowledge in various subject areas, but who are not always able to adapt to real hardships of life and socio-economic challenges.

Moreover, this model deprives pupils of autonomy and personal responsibility for their educational achievements or failures. This shortage of learning autonomy destructively affects the student's worldview. Inactive tasks and uncreative teaching makes the student's thinking more inert and stereotyped; routine and unproductive exercises constraining independence eventually shape people seeking reproductive, uncreative way of life.

Learning is one of the most important spheres for students to fulfil their own potentials. Therefore, educators should realize that externally imposed goals are rarely conducive to progress as well as academic success for alien goals and interests hardly brings the student joy and satisfaction with their achievements.

It is proved that the higher the intellectual activity of the student the more they value independence and ability to make responsible decisions. There is also a feedback: learning autonomy does not only encourage students to be creative, but also greatly improves their thinking and leads to delight in learning, etc. Simultaneously, more developed and independent students tend to demand better content and methods of teaching.

\subsubsection{Innovative Roles of the Foreign Language Teacher}

Thus, what is more effective model of foreign languages learning like? What are its main characteristics?

Recognizing the students' active position in learning, the teacher organizes training activities to facilitate, firstly, learners' knowledge discovering; secondly, control their own progress in language; thirdly, successful unravelling of academic challenges in interpersonal interaction (Ivanova, 2002, p. 80). Thus, the main task of the teacher is to disentangle the student from the educational labyrinth using all modern teaching tools.

The new educational model implies that the teacher is always next to the pupil and encourages them to participate actively in their own language acquisition and in developing short- and long-term life goals. Similarly, the teacher stimulates students to take responsibility for their own self-development and sustaining warm and friendly relationships with others. To achieve this educational objective the teacher must acquire completely new functions, that is, they will have to take the roles of a consultant, navigator, mentor and helper. Guided by classroom situations the teacher assumes the role of either a speech partner or consultant, an initiator or navigator of communication, and, if necessary, an arbitrator. Thus, the targeted assistance in a problem situation requires from the teacher the functional role of a mentor. While helping children solve educational tasks teachers turn into consultants and, finally, classroom management forces teachers to develop immediate and long-term learning goals and define when they will be achieved, that is to say, it forces the teacher to act as a navigator.

\section{Results and Discussion}

\subsection{Competence-Based Approach to Foreign Language Teaching}

Best practices for foreign language teaching show that effectiveness of classroom language teaching depends on how far the teacher can encourage students to use the acquired language for communication and self-expression. Similarly, it depends on how well the student can use the language for more profound learning of their own and 
the target language culture as well as for consolidating knowledge and concepts from other subject areas. Foreign language lessons are designed to develop students' initiative, intensify their intellectual activities, promote organizational forms of cooperation, such as simulation activities, role-playing, project work, working in triads, groups, trainings (Zimnyaya, 1997, p. 280). Another important aspect is the design of self-study work and extracurricular activities. (How can one learn the language having only 3 hours per week?)

In other words, foreign languages should be acquired through various activities that are organically interwoven into a unified system of knowledge and skills, which build up the general education.

In this regard, one of the main objectives for school administration is creation of foreign language environment. Since regular Russian schools lack both native speakers and managing staff proficient in foreign language, it is difficult to achieve this aim. What is especially challenging is the system of out-of-class activities designed to enhance foreign language skills. Experience of successful schools shows that organization of foreign language theatres, songs and essays competitions, watching well-known Russian cartoons dubbed in a foreign language, pen pal clubs or communication via Skype with peers speaking the target language, etc. effectively compensate for the absence of foreign language environment.

In recent year's school and inter-school summer/winter camps aimed at fostering foreign language communication have proven to be highly efficient. Likewise, we believe that schools practicing individual and group tutoring merit greater attention.

However, as noted above, the work requires a different and more effective model of managing extracurricular activities. Important components of this model are methodology provision for organizers of extracurricular activities, which is intended for increasing foreign language competence of teaching and managerial staff, and development of a system for financial stimulation of teachers. At the same time, the change to a new model of management is quite complex and requires qualified scientific and methodological support as long as appropriate organizational and economic mechanism is formed. Implementation of this model could start with launching corporate courses based on a curriculum designed by a qualified scientific and teaching staff. In particular, the Volga Region Centre for Further Training and Professional Retraining of Kazan Federal University have already had the staff and programmes needed for such courses.

Unfortunately, to date, teacher-training institutions have not been able to shift their focus on training the teacher skilled in these new functions. There is still a need to raise the quality of fundamental teacher education including expertise in studies of verbal communication.

The new generation of FSES fundamentally differs from the previous ones in terms of structure and methodology. Structurally, the FSES comprise three areas of requirements to, firstly, the design of school curricula, secondly, academic achievements, and, thirdly, learning environment facilitating the academic achievements. Methodologically, the FSES have changed essential principles of assessing the Standards requirements to academic achievements. Consequently, the important benchmarks for assessing are the results of implementation and development of the basic educational programme at students, teaching staff and educational institutions (EI) levels.

Thus, the achievement of the FSES establishes the vector of management activities at all levels, from federal, regional and municipal to intra-school management.

\subsection{Developing the Standards Proficiency in Foreign Language Teaching}

\subsubsection{The Three Areas of the Standards Requirements}

In the context of new standards EI management are expected to assist in enhancing the quality of teaching through tackling two problem areas; the first one involves motivation and target problems, the other area includes resources and technologies tasks. All these tasks are aimed at achieving the three areas of the Standards Requirements (3Rs) to:

- Academic achievements based on the development of basic educational programme (R1);

- Structure of the basic educational programme (R2);

- Learning environment for realizing the basic educational programme (R3).

Efficiency of these solutions relies primarily on the competencies of EI management in these 3Rs areas, that is, R1, R2 and R3. Our concept of the FSES implementation into foreign language school education focuses attention on improving the competence of managerial and teaching staff in these 3 Rs. 


\subsubsection{Proficiency in R1}

Speaking about Requirements for the educational programmes development, one should note that teachers of foreign languages, as well as EI managers, need considerably more expertise in setting current, intermediate and ultimate academic goals for second language acquisition. If the older standards focused on subject-related outcomes, the new ones are equally focused on meta-subject (regulatory, cognitive, communicative universal academic actions) and personal results.

In other words, the new standards claim that apart from discipline-centred knowledge and the ability to apply this knowledge in everyday life academic outcomes also imply expertise in setting learning goals, planning activities, monitoring and assessing the performance. The student must learn cognitive universal actions, namely, learn to acquire knowledge on their own using a wide range of learning tools, including textbooks, dictionaries, language equipment, information resources of a computer, smart phones, etc. In this line, added significance assumes communicative universal academic actions, involving the ability to clearly express their thoughts, listen carefully to the interlocutor, competently build a conversation, follow ethical standards in the conversation and clearly articulate their arguments while debating.

Moreover, what should the teacher and school director know and be able to do to enable the student to achieve the goals at every stage? A set of necessary competencies is stipulated by the requirements to the structure of the basic educational programme. In addition to goal-settings, the new Standards require expertise in development and implementation of meta-results and the assessment of academic achievements, new learning technologies and content and socialization methods grounded on the Concept of Moral and Spiritual Education and Development of Russian Schoolchildren. It is necessary to develop and implement meaningful, in the context of foreign language acquisition, curricula for out-of-school activities promoting healthy and safe lifestyles.

What resources can help students immerse into the target language? This objective requires new generation of learning and teaching aids. One should remember that the teacher highly relies on the textbook. However, older textbooks drill on translation, reading, grammar, writing to the detriment of communication. There is an urgent need in course books, phrasebooks, a wide range of audio and visual aids (movies, cartoons), games, nursery rhymes, information and communication resources enabling to communicate in the information network. There is a lot of work to do to equip schools with new learning tools and instructing teachers to use them effectively.

Teacher needs to activate the student's personal motives for learning. On the one hand, this can be inspired by realizations of their outer, social, and inner, personal, aspirations. A teacher must learn to accurately determine when the student is trying to overcome difficult milestones in second language acquisition. On the other hand, it is necessary to increase or even waken the cognitive motivation, freed from external coercion (i.e., when the student learns the language not "for marks' sake", but to learn something new or discover something new for themselves, with no fear to make mistakes) (Ivanova, 2002, pp. 91-92).

It is noted that long-term motives are ineffective than the system of short-term motives, which demands language environment contributing to foreign language speaking in the classroom, outdoors, when playing games or visiting the theatre, etc. Such motivation encourages students to employ languages in everyday situations and master their language skills. It also allows the teacher to maintain a higher motivation throughout learning process and develop students' initiatives and autonomy. In this regard, we assume that it is more effective to plan the training process using the "small steps technology" since success in simple tasks is more productive and can cause a sequence of small victories. Undoubtedly, a broader context of general cognitive and social motives can also facilitate the growth of motivation. For instance, a want to comprehend foreign movies and songs or desire to communicate with native speakers on the Internet or in live may also motivate to learning the foreign language.

\subsubsection{Proficiency in R2}

Following the key elements of the FSES, the next important requirement of the Standards focuses on forming the system of language acquisition management in accordance with the new educational goals. In this context, teachers will have to master the technology of developing universal academic actions (UAA), including communicative, regulatory, and educational activities. In doing so, teachers will have to transform the student from the object of learning to the subject of educational activity. These innovations assume development and application of a new educational results-based assessment system, which assesses not only acquired knowledge and skills but tools of students' learning activity as well, i.e., their UAA. In this respect, the teacher evaluates activities, enabling the student to acquire new competencies. This implies that schools create fundamentally new conditions that ensure language and speech activity of children. 
Firstly, it would be useful to develop language milieu that can significantly reinforce students' communication activity with various modes of study. This refers to classroom as well as extracurricular use of a foreign language in summer schools, summer camps, out-of-class activities in the holidays or home-reading, listening to nursery rhymes and teenage songs, watching cartoons and movies in the original, chatting on Skype with peers from abroad, and many others. "Out-of-class use makes student language more varied and interactive, extending student's language skills beyond the academic register which classroom language requires." (Lo Bianco et al., 2009, p. 34)

Secondly, it is necessary to intensify interdisciplinary links, including immersion education (Fortune \& Tedick, 2008), which relies on the idea that children learn language by focusing on subject content. Immersion education may be a counterbalance to the lack of the natural target language environment. According to B. H. Beardsmore, foreign language acquisition can be enhanced if explicit teaching complements the immersion: "when explicit teaching is added to immersion, either before or alongside the use of the target language as a medium of instruction, significant improvements have been recorded" (Beardsmore, 1993). Thus, there is a need in special immersion programmes endorsing the use of the target language to teach certain subjects, literature, music, fundamentals of health and safety in particular. The study of the latter is important in the context of forming basic survival skills and personal safety. For instance, when abroad, children should be able to ask for help or directions, inform about their ailments, notify the police of a loss, describe their belongings and documents, talk about their place of residence and purpose of visit to the country, and others.

\subsubsection{Proficiency in R3}

For the first time the FSES have defined requirements to learning conditions ensuring academic achievements, including second language acquisition. Principally, a set of requirements is aimed at coaching a qualified staff. It is no secret that students' academic achievements are highly dependent on the teacher's professionalism. In this respect, one of the foci of interest for school management today is to help educators organize teaching within the systemic-activity approach (Asmolov, 2009):

- Recognizing new educational tasks identified in the Intended academic outcomes for second language education;

- Mastering communicative language teaching;

- Acquiring new major methodological innovations of CLIL, content and language integrated learning (Coyle, 2007), and immersion education methodology to design and promote subject and the target language integrated learning milieu;

- Mastering current techniques for measurement and evaluation of learners' outcomes at all stages of the second language acquisition;

- Using e-learning tools and Internet resources engaging online communication with native speakers;

- Applying problem-solving, searching and project-work technologies, advancing learners' autonomy in goals setting, actions taking and progress making;

- Developing technology of universal academic actions helping to tackle the problem of "learning to learn" in the second language information environment.

The imperative is to help foreign language teachers not to give token attention to current educational goals. Misunderstanding of these goals brings the teacher full circle back to the outdated, inefficient methods of language teaching. The essence of these new challenges is in sharing responsibility between the teacher and the student. The teacher takes responsibility for developing the student's regulatory, communicative, cognitive universal academic actions (UAA), ICT competence and projects development. This involves a different system of planning teachers' work and learners' performance including students' good communication skills to respond to all academic challenges.

In the transition to new learning outcomes, other methods for assessment of educational achievements are needed. For example, how to assess the progress in meta-subject achievements: regulatory, communicative or cognitive UAA? How to assess the growth of students' knowledge and skills gained due to the new educational tools as UAA?

Traineeship programmes of the Volga Region Centre for Further Training and Professional Retraining of Kazan Federal University show that foreign language teachers often experience a significant decrease in their foreign language speaking skills. By turn, this demonstrates the quality of developing speech skills for students. The aim of our courses for foreign language teachers is to help them to overcome complexes associated with the loss of 
language expertise. This is of primary importance for rural schoolteachers who do not have an access to professional level of foreign language communication for many years.

\section{Conclusion and Recommendations}

Good teaching is the single central factor in foreign language acquisition and this in turn depends largely on the quality of teacher education and the susceptibility of school administration implementing educational reforms to teachers' needs. In the context of foreign language teaching successful schools should take account of such key indicators as creating the atmosphere which can boost children's intrinsic motivation to learn a foreign language; forming students' independence in communication-based activities; extending the scope of foreign language communication; generating conditions allowing the student to evaluate their results achieved in foreign language learning.

\section{Acknowledgments}

The work is performed according to the Russian Government Program of Competitive Growth of Kazan Federal University.

\section{References}

Asmolov, A. G. (2009). Systemic-activity approach to development of new Standards. Pedagogika, 4, 18-22.

Beardsmore, B. H. (1993). The European School Model. In B. H. Beardsmore (Ed.), European Models of Bilingual Education (pp. 121-154). Bristol: Longdunn Press.

Bolitho, R. (2012). Projects and programmes: Contemporary experience in ELT change management. In C. Tribble (Ed.), Managing Change in English Language Teaching: Lessons from Experience (pp. 33-45). London: British Council.

CILT. (2006). Effects on the European Union Economy of Shortages of Foreign Language Skills in Enterprise. Retrieved from http://heimatkunde.boell.de/sites/default/files/downloads/integration /elan_final_report_english.pdf

Commission of the European Communities. (2008). Multilingualism: an asset for Europe and a shared commitment. Retrieved from http://eur-lex.europa.eu/legal-content/EN/ALL/?uri=CELEX:52008DC0566

Conception on Modernization of Russian Education for the Period up to 2010. (2002). Retrieved from http://www.edu.ru/db/mo/Data/d_02/393.html

Conception on subject-oriented instruction at higher levels of general education. (2002). Retrieved March 4, 2012, from http://www. ug.ru/old/02.42/t9.htm

Council of the European Union. (2008). Council Resolution on a European strategy for multilingualism. Retrieved August 16, 2014, from Council of the European Union: http://www.consilium.europa.eu/ueDocs/cms_Data/docs/pressData/en/educ/104230.pdf

Coyle, D. (2007). CLIL: towards a connected research agenda for CLIL pedagogies. International Journal of Bilingual Education and Bilingualism, 10(5), 543-562.

DEEWR. (2009). National Asian Languages and Studies in Schools Program-Strategic Collaboration and Partnership Fund Information Pack-Round One 2009. Retrieved from http://www.deewr.gov.au/Schooling/NALSSP/Documents/

Education Act. (2012). Retrieved from http://www.rg.ru/2012/12/30/obrazovanie-dok.html

Educational standard of secondary (complete) general education for the foreign language. (2012). Retrieved from http://www.agaryova.ru/fgos-vtorogo-pokoleniya/2012-04-18/obrazovatelnyy-standart-srednegopolnogo-obschego-obrazovaniya-po-inostrannomu-yazyku

European Commission. (2007). ELAN: Impact on the economy of the EU of language skills shortages in enterprise. Retrieved from http://europa.eu/rapid/press-release_MEMO-07-79_en.htm?locale=fr

European Commission. (2012). Europeans and their Languages. Special Eurobarometer 386. Brussels: European Commission. Retrieved from http://ec.europa.eu/public_opinion/archives/ebs/ebs_386_en.pdf

Eurostat. (2014, May 14). Foreign language learning statistics. Retrieved from http://epp.eurostat.ec.europa.eu/statistics_explained/index.php/Foreign_language_learning_statistics

Fortune, T. W., \& Tedick, D. J. (Eds.). (2008.). Pathways to multilingualism: Evolving perspectives on immersion education. Clevedon, UK: Multilingual Matters. 
FSES for general education (5-9 classes). (2010). Retrieved from Website of Ministry of Education and Science of Russian hederation $\quad$ http:/минобрнауки.рф /\%D0\%B4\%D0\%BE\%D0\%BA\%D1\%83\%D0\%BC\%D0\%B5\%D0\%BD \%D1\%82\%D1\%8B/938

FSES for primary general education (1-4 classes). (2009). Retrieved from Website of Ministry of Education and Science of Russian $\quad$ Federation $\quad \mathrm{http} / /$ минобрнауки.pф/\% D0\%B4\%D0\%BE\%D0\%BA\%D1\%83\%D0\%BC\%D0\%B5\%D0\%BD\%D1\%82\%D1\%8B/922

FSES for secondary (complete) general education (10-11classes). (2010). Retrieved from Website of Ministry of Education and Science of Russian Federation http://минобрнауки.p $\phi / \%$ D0\%B4\%D0\%BE\%D0\%BA\%D1\%83\%D0\%BC\%D0\%B5\%D0\%BD\%D1\%82\%D1\%8B/2365

Hayes, D. (2012). Planning for success: Culture, engagement and power in English language education innovation. In C. Tribble (Ed.), Managing Change in English Language Teaching: Lessons from Experience (pp. 47-60). London: British Council.

Ivanova, S. P. (2002). Teacher of the XXI century: Noo-psychological approach to analysing professional and personal readiness for pedagogical activity. Pskov: PSPI named after S.M. Kirov.

Kouzovlev, V. (2014). How to teach today not to feel shameful tomorrow? (Publishing House "Prosveshenie") Retrieved from "Foreign languages" Internet edition for teachers http://iyazyki.ru/2014/02/today-tomorrow/\#more-14509

Lo Bianco, J., \& Slaughter, Y. (2009). Second Languages and Australian Schooling. Australian Council for Educational Research. Retrieved from http://www.acer.edu.au

Makrotova , G. (2014). Use of Internet in cognitive activity of high-schoolers: Cultural approach. Moscow: Litres. Retrieved from http://books.google.ru/books?id=SxuBAwAAQBAJ\& printsec $=$ frontcover $\& \mathrm{hl}=\mathrm{ru} \# \mathrm{v}=$ onepage $\& \mathrm{q} \& \mathrm{f}=$ false

MCEETYA. (2005). National Statement for Languages Education in Australian Schools: National Plan for Languages Education in Australian Schools 2005-2008. Adelaide: The State of South Australia: Department of Education and Children's Services.

Ministry of Education and Science of Russian Federation. (2010). Approximate basic educational programme of primary general education. Retrieved from Website of Ministry of Education and Science of Russian Federation http://минобрнауки.pф/\%D0\%B4\%D0\%BE\%D0\%BA\%D1\%83\%D0\%BC\%D0\%B5\%D0\%BD\%D1\%82 \%D1\%8B/922/\%D1\%84\%D0\%B0\%D0\%B9\%D0\%BB/227/10.07.20-\%D0\%9F\%D1\%80\%D0\%B8\%D0\% BC\%D0\%B5\%D1\%80\%D0\%BD\%D0\%B0\%D1\%8F_\%D0\%BF\%D1\%80\%D0\%BE\%D0\%B3\%D1\%80\% D0\%B0\%D0\%BC\%D0\%BC\%D0\%B0_\%D0\%9D\%D0\%9E\%D0\%9E.pdf

Murray, D. E., \& Christison, M. (2012). Understanding innovation in English language education: Contexts and issues. In T. Christopher (Ed.), Managing Change in English Language Teaching: Lessons from Experience (pp. 61-74). British Council.

National educational initiative "Our New School". (2010). Retrieved from Website of Ministry of Education and Science of Russian Federation http://old.mon.gov.ru/dok/akt/6591/

Partnership for 21st Century Skills. (2011, March). 21st Century Skills World Languages Map. Retrieved from http://www.p21.org/storage/documents/Skills\%20Map/p21_worldlanguagesmap.pdf

Plakhova, L. A. (2013). Changes of notional reference points: From successful school to the child's achievements. Retrieved from http://standart.edu.ru/doc.aspx?DocId=10684

Presidency Conclusions. (2002). Barcelona: European Council. Retrieved August 15, 2014, from http://www.consilium.europa.eu/ueDocs/cms_Data/docs/pressData/en/ec/71025.pdf

Prosveshenie. (2011). Fundemental core of syllbus for general complete education (4th ed.).

Safonova, V. V., \& Solovova, E. N. (2008). Significance of the foreign language in school education. Retrieved from Laboratory of e-learning http://distant.ioso.ru/for\%20teacher/conc.htm

Savinov, E. (2011). Approximate basic educational programme of educational institutions-General basic school. Moscow: Prosveshenie.

Savinov, E. S. (2010). Approximate basic educational programme of educational institutions-Primary school (2nd ed.). Moscow: Prosveshenie. 
Tribble, C. (Ed.). (2012). Managing Change in English Language Teaching: Lessons from Experience. London: British Council. Retrieved from http://www.britishcouncil.org

Voitovich, I. (2012). Foreign languages in the context of life-long education. Izhevsk: Udmurt University.

Zimnyaya, I. A. (1997). Pedagogical psychology. Rostov-on-Don: Phoenix.

\section{Copyrights}

Copyright for this article is retained by the author(s), with first publication rights granted to the journal. This is an open-access article distributed under the terms and conditions of the Creative Commons Attribution license (http://creativecommons.org/licenses/by/3.0/). 